\title{
Copacetic herbal extraction techniques and diabetes induction methods for developing countries
}

\author{
Md. Mahmudul Amin and Shonkor Kumar Das
}

Bioresearch Laboratory (Cancer and Herbal Research Center), Dept. of Anatomy and Histology, Faculty of Veterinary Science, Bangladesh Agricultural University, Mymensingh-2202, Bangladesh

$\bowtie$ skdas76@yahoo.com (Das, S. K.), ( +880-1716855186, Published: 26 April 2016

\begin{abstract}
Extraction is an empirical exercise for the discovery of bioactive constituents from the plant materials. Selection of a suitable extraction technique is also important for the standardization of herbal products and to eliminate unwanted material by treatment with a selective solvent known as "menstrum". Traditional conventional methods such as maceration, rotary evaporation, soxhelation, percolation, lyophilization, infusion, decoction etc are more cheap and appropriate for developing countries rather than fast and environmentally friendly green extraction techniques like ultrasound assisted solvent extraction, microwave assisted solvent extraction and supercritical fluid extractions for phytochemical processing of medicinal plants. Moreover, plant-derived phytochemicals have established their role for possible use in diabetes treatment which is the world's largest endocrine disease associated with increased morbidity and mortality rate. Several experimental models are used to study pathophysiological factors involved in diabetes and to assess the efficacy of herbal antihyperglycemic agents. Today different strains of laboratory animals are available and therapeutic studies on diabetes are mostly carried out on these models. In animals, it can be induced by partial pancreatectomy or by the administration of diabetogenic drugs such as alloxan, streptozotocin, ditizona and anti-insulin serum. Hence, the review is aiming to draw attention of the relevant researchers to the convenient use of suitable extraction technique and diabetogenic drugs for developing countries.
\end{abstract}

Key Words: Copacetic, Herbal extraction, Diabetes, Induction method and Developing countries

Cite article: Amin, M. M. \& Das, S. K. (2016). Copacetic herbal extraction techniques and diabetes induction methods for developing countries. Journal of Bioscience and Agriculture Research, 08(01), 703-709.

Article distributed under terms of a Creative Common Attribution 4.0 International License.

\section{Introduction}

Plants are still important sources of medicines, especially in developing countries that still use plant-based traditional medicine for their healthcare (Salim et al., 2008). Plants are an important source of bioactive molecules for drug discovery. Isolated bioactive molecules serve as starting materials for laboratory synthesis of drugs as well as a model for the production of biologically active compounds (Dhanani et al., 2013). Phytochemical processing of raw plant materials is essentially 
required to optimize the concentration of known constituents and also to maintain their activities (Satyanshu, 2015). Extraction is the separation of medicinally active portions of plant tissues using selective solvents through standard procedures. The products so obtained from plants are relatively complex mixtures of metabolites, in liquid or semisolid state or in dry powder form (after removing the solvent), \& are intended for oral or external use (Tiwari et al., 2011). The purpose of standardized extraction procedures for crude drugs (medicinal \& aromatic plant parts) is to attain the therapeutically desired portions (Tiwari et al., 2011). Various extraction techniques most commonly used include conventional techniques such as maceration, percolation, infusion, decoction, hot continuous extraction etc. Recently, alternative methods like ultrasound assisted solvent extraction (UASE), microwave assisted solvent extraction (MASE) and supercritical fluid extractions (SFE) have gained increasing interest during the last three decades though these technologies are quite expensive (Saurabh et al., 2015).

As about $50 \%$ of the Bangladeshi populations are at risk of diabetes each year, the majority of people especially in rural areas, use herbal medicine alone or alongside prescription drugs for diabetes management (Amin et al., 2015). Experimental models play an important role in understanding such a disease, which is treatable only. In animals, it can be induced by partial pancreatectomy or by the administration of diabetogenic drugs such as alloxan, streptozotocin, ditizona and anti-insulin serum (Carvalho et al., 2003). These agents selectively destroy the $\beta$-cells of islets of Langerhans. In most laboratories this diabetogenic drug induced experimental model used more conveniently as alternative model in therapeutic studies on diabetes (Carvalho et al., 2003). This review provides useful resources to draw attention of the relevant researchers on the available phytochemicals extraction techniques and diabetes induction methods and also give importance on their more rational use in the developing countries like Bangladesh.

\section{Methodology}

This review article has been prepared from secondary study materials such as published journal articles, review papers, conference papers \& reports, technical and theoretical notes, reports, books and relevant information found from various online sources.

\section{Discussion}

\section{Extraction process}

There are a number of extraction techniques used by the scientists in the developing countries, given in a flow chart (Figure 01). These are discussed below.

Rotary evaporation: Plants parts are first collected and identified by the specialist. Then they are washed carefully and dried immediately either in an artificial environment at low temperature (50$60^{\circ} \mathrm{C}$ ) or dried preferably in shade so as to bring down the initial large moisture content to enable its prolonged storage life. The dried portions are then grinded using grinder to make fine powder. The powder is then dissolved in alcohol. The suspension is filtered with filter paper and dried by rotary evaporator and alcoholic extract is obtained. It is finally stored in airtight container in refrigerator for further use (Kulasekharam, 2014; Bhuyan et al., 2010; Nahar et al., 2010; Sikder et al., 2011; Sophia and Manoharan, 2007; Varma et al., 2009; Zulfiker et al., 2011).

Soxhelation: Collected and identified plants parts are carefully washed and dried in sunlight. The dried portions are then grinded to make fine powder. The powder is packed separately in the Soxhlet apparatus and extracted with alcohol, until the completion of the extraction. The extract is filtered while hot and the resultant extract is distilled in vacuum under reduced pressure in order to remove the solvent completely and later dried in a desiccator. After that alcohol extract is kept in air tight container for further study (Farswan et al., 2009; Maurya et al., 2011; Prasad et al., 2014; Sachan et al., 2009; Samyal et al., 2014; Singh and Gupta, 2007; Vivek et al., 2010).

Percolation: The experimented parts are first washed well and dried at room temperature and coarsely powdered. The powder is extracted with hexane to remove lipids. It is then filtered and the 
filtrate is discarded. The residue is successively extracted with methanol using cold percolation method. The extract is stored at $-70^{\circ} \mathrm{C}$ (Heroor et al., 2013; Mastan et al., 2009; Patil et al., 2010).

Lyophilization: The plant parts are washed with clear water and then ground for 10 min in a mixer along with the distilled water $(500 \mathrm{ml})$. It is allowed to stand overnight and then filtered through several layers of muslin cloth. The whole procedure is carried out in cold condition at $4 \stackrel{\circ}{\circ}$. The filtrate is centrifuged in a refrigerated centrifuge at $10,000 \mathrm{rpm}$. The supernatant is lyophilized to get a thick paste of water extract (Ramana et al., 2011; Rekha et al., 2008).

\section{There are four (4) common extraction processes as described below:}

Plants parts are collected and identified by the specialist

Carefully washed with distilled water and dried

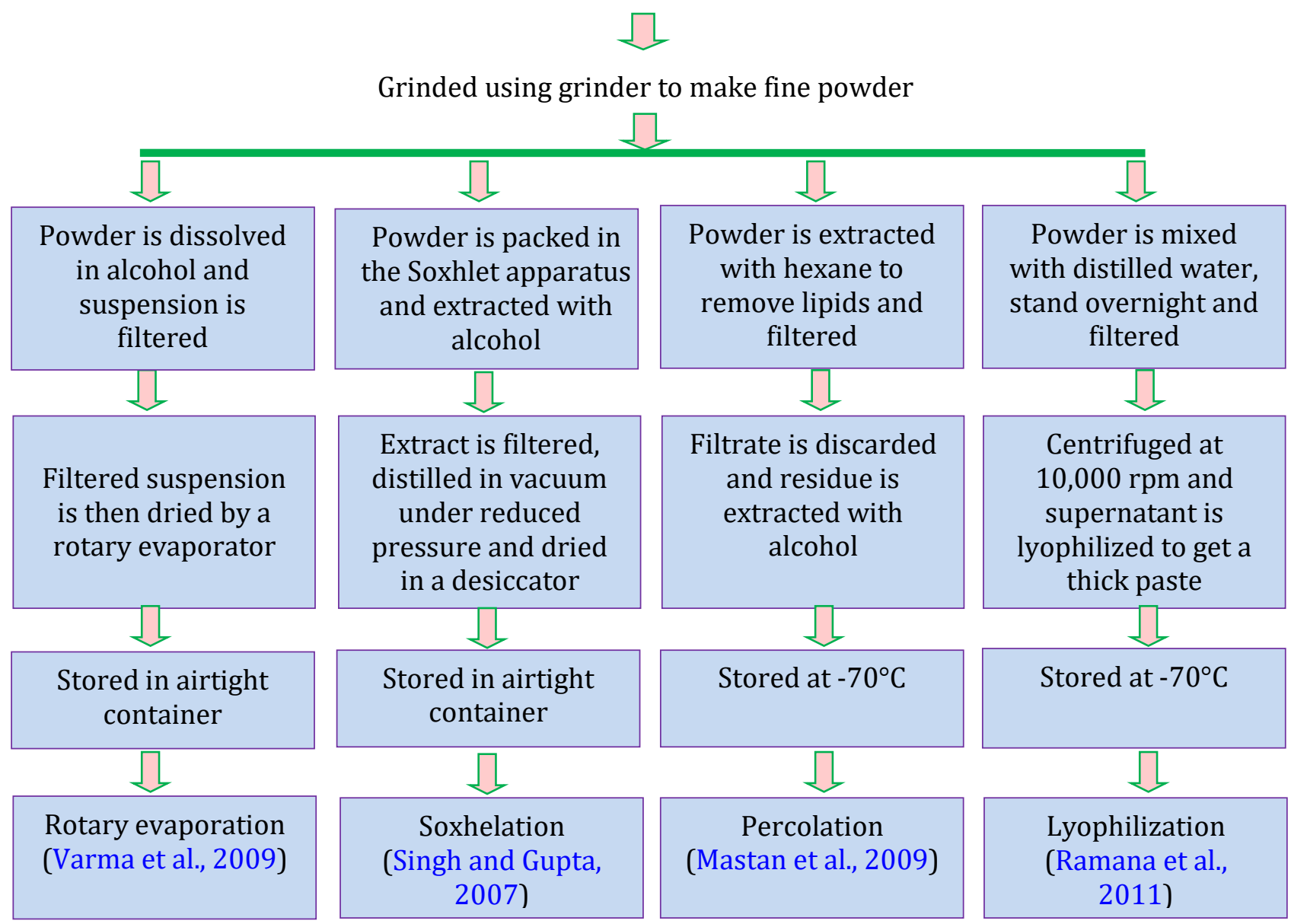

Figure 01. Brief illustration (flow chart) of the extraction processes.

In the developing countries like Bangladesh, rotary evaporation method is chiefly used for extraction as it allows for quick, gentle evaporation of solvents; even it is relatively easier for the inexperienced users. New techniques such as supercritical fluid extraction (SFE), microwave-assisted extraction, solid phase extraction, chromatographic fingerprinting and marker compound analysis, chromatographic techniques (liquid chromatography, gas chromatography, supercritical fluid chromatography) are highly expensive but are particularly useful when one has many samples to do in parallel.

\section{Diabetes induction methods}

Different models to induce experimental diabetes mellitus are:

a) Alloxan induced diabetes 
b) Streptozotocin induced diabetes

c) Other diabetogenic compounds

d) Pancreatectomy in dogs

e) Hormone induced diabetes

f) Insulin deficiency due to insulin antibodies

g) Virus induced diabetes (Grover et al., 2011)

Table 01. Diabetes induction methods by using Streptozotocin

\begin{tabular}{|c|c|c|c|}
\hline Dose & Animals used & References & Route \\
\hline \multicolumn{4}{|c|}{ 1. Streptozotocin in physiological saline @ } \\
\hline - $35 \mathrm{mg} / \mathrm{kgbw}$ & Sprague Dawley rat & Jonnalagadda et al., 2013 & \multirow{5}{*}{$\begin{array}{l}\text { Single intra- } \\
\text { peritoneal } \\
\text { injection }\end{array}$} \\
\hline - $45 \mathrm{mg} / \mathrm{kgbw}$ & Wister albino rat & $\begin{array}{l}\text { Kulasekharam, 2014; } \\
\text { Maurya et al., } 2011\end{array}$ & \\
\hline - $50 \mathrm{mg} / \mathrm{kgbw}$ & $\begin{array}{l}\text { Sprague-Dauley rat } \\
\text { Wister albino rat }\end{array}$ & $\begin{array}{l}\text { Ramana et al. } 2011 \\
\text { Sridhar et al., 2005; } \\
\text { Varma et al., 2009 }\end{array}$ & \\
\hline - $55 \mathrm{mg} / \mathrm{kgbw}$ & Wistar rat & Rekha et al., 2008 & \\
\hline - $90 \mathrm{mg} / \mathrm{kgbw}$ & $\begin{array}{l}\text { Long-Evans rat } \\
\text { Wistar albino rat }\end{array}$ & $\begin{array}{l}\text { Bhuyan et al., } 2010 \\
\text { Farswan et al., } 2009\end{array}$ & \\
\hline \multicolumn{4}{|c|}{ 2. Streptozotocin in physiological saline @ } \\
\hline - $55 \mathrm{mg} / \mathrm{kgbw}$ & Wistar rat & Ahmed and Urooj, 2009 & $\begin{array}{l}\text { Single } \\
\text { intramuscular } \\
\text { injection }\end{array}$ \\
\hline \multicolumn{4}{|l|}{ 3. In physiological saline } \\
\hline $\begin{array}{l}\text { Nicotinamide @ } \\
120 \mathrm{mg} / \text { kgbw + } \\
\text { Streptozotocin @ } \\
60 \mathrm{mg} / \mathrm{kgbw}\end{array}$ & Wistar albino rat & $\begin{array}{l}\text { Samyal et al., 2014; } \\
\text { Sarma, } 2014\end{array}$ & $\begin{array}{l}\text { Single intra- } \\
\text { peritoneal } \\
\text { injection }\end{array}$ \\
\hline
\end{tabular}

Table 02. Diabetes induction methods by using Alloxan Monohydrate

\begin{tabular}{|c|c|c|c|c|}
\hline Dose & & Animals used & References & Route \\
\hline \multicolumn{5}{|c|}{ 1. Alloxan monohydrate in physiological saline @ } \\
\hline & $60 \mathrm{mg} / \mathrm{kgbw}$ & Wistar albino rat & Singh and Gupta, 2007 & \multirow{2}{*}{$\begin{array}{l}\text { Single } \\
\text { intravenous } \\
\text { injection }\end{array}$} \\
\hline & $150 \mathrm{mg} / \mathrm{kgbw}$ & Sprague-Dawley rat & Sachan et al., 2009 & \\
\hline \multicolumn{5}{|c|}{ 2. Alloxan monohydrate in physiological saline @ } \\
\hline & $\begin{array}{l}100 \mathrm{mg} / \mathrm{kgbw} \\
110 \mathrm{mg} / \mathrm{kgbw} \\
120 \mathrm{mg} / \mathrm{kgbw}\end{array}$ & Albino rat & $\begin{array}{l}\text { Mastan et al., } 2009 \\
\text { Nahar et al., } 2010 \\
\text { Nair and Santhakumari, 1986; } \\
\text { Vivek et al., } 2010\end{array}$ & \multirow{2}{*}{$\begin{array}{l}\text { Single intra- } \\
\text { peritoneal } \\
\text { injection }\end{array}$} \\
\hline & $150 \mathrm{mg} / \mathrm{kgbw}$ & $\begin{array}{l}\text { Rats } \\
\text { Long Evan's rat } \\
\text { Albino Wistar rat } \\
\text { Swiss albino mice }\end{array}$ & $\begin{array}{l}\text { Heroor et al., } 2013 \\
\text { Sikder et al., } 2011 \\
\text { Sophia and Manoharan, } 2007 \\
\text { Zulfiker et al., } 2011\end{array}$ & \\
\hline \multicolumn{5}{|c|}{ 3. Aqueous solution of Alloxan monohydrate } \\
\hline & $\begin{array}{l}80 \mathrm{mg} / \mathrm{kgbw} \\
110 \mathrm{mg} / \mathrm{kgbw} \\
150 \mathrm{mg} / \mathrm{kgbw} \\
\end{array}$ & $\begin{array}{l}\text { Wistar albino rat } \\
\text { Albino Wistar rat } \\
\text { Swiss albino mice } \\
\end{array}$ & $\begin{array}{l}\text { Prasad et al., } 2014 \\
\text { Patil et al., } 2010 \\
\text { Sufiyan et al., } 2014 \\
\end{array}$ & $\begin{array}{l}\text { Single intra- } \\
\text { peritoneal } \\
\text { injection }\end{array}$ \\
\hline
\end{tabular}

Animal models of diabetes are increasingly being used for pathophysiology and pharmacological studies of diabetes mellitus. Advantages of animal studies in the examination of alternative medicines and their efficacy include the ability to define experimental conditions more tightly and to undertake more detailed studies of the biologic effects of the agents being used (Emam, 2012). Streptozotocin 
and Alloxan monohydrate-induced hyperglycaemia in animals are considered to be a good experimental model since they are less toxic than other chemical agents inducing diabetes. The methods for diabetes induction by using streptozotocin and alloxan monohydrate are summarized in (Table 01) and (Table 02). Other than streptozotocin and alloxan monohydrate, dithizone or goldthioglucose can be used as diabetogenic agents but those are costly and hardly available. Pancreatectomy and hormone induced diabetes are mostly suitable for dogs and cats. Other methods such as insulin deficiency due to insulin antibodies or virus induced diabetes are difficult to execute.

Streptozotocin is a naturally occurring chemical and carries a substantial risk of toxicity. Alloxan monohydrate is highly toxic to the liver and the kidneys. So the lowest dose i.e., @ 35mg/kgbw single, intra-peritoneal injection of streptozotocin and $6 \mathrm{mg} / 100 \mathrm{gbw}$ single intravenous injection of alloxan monohydrate would be safer for diabetes induction in the animals.

\section{Conclusion}

Despite all of the advances made by the pharmaceutical industry in the development of novel and highly effective medicines for the treatment of a wide range of diseases, there has been a marked increase in the use of herbal medicines even including the more affluent countries of the world (Doughari, 2012). For the separation of medicinally active portions of plant tissues, suitable extraction method is inevitable. Each method has its own advantage or disadvantage. Hence, to make the extracts available to the mass people, cheap and safe methods such as the rotary evaporation method may be appropriate in our country. On the other hand, diabetogenic drugs are easy to administer for diabetes induction than other known diabetes induction methods and the best known drug-induced diabetes model is the alloxan diabetes. Hence, the review will create some new ideas in the avenue of research and will offer better opportunities to the scientists to have a convenient and more suitable extraction technique and diabetes induction method.

\section{References}

[1]. Ahmed, F. \& Urooj, A. (2009). Glucose-lowering, hepato-protective and hypolipidemic activities of stem bark of Ficus racemosa in streptozotocin-induced diabetic rats. Journal of Young Pharmacists, 1(2), 160-164. http://dx.doi.org/10.4103/0975-1483.55749

[2]. Amin, M. M., Sonali, B. \& Das, S. K. (2015). Anti-diabetic potential of Ficus racemosa: current state and prospect especially in the developing countries. Journal of Bioscience and Agriculture Research, 5(2), 65-72. http://dx.doi.org/10.18801/jbar.050215.56

[3]. Bhuyan, Z. A., Begum, R., Nuruzzaman, M., Shahdat, H. \& Ishtiaq, M. (2010). Antidiabetic effect of Syzygium cumini L. seed on type 2 diabetic rats. Dhaka University Journal of Biological Sciences, 19, 157-164. http://dx.doi.org/10.3329/dujbs.v19i2.8959

[4]. Carvalho, E. N., Carvalho, N. A. S. \& Ferreira, L. M. (2003). Experimental model of induction of diabetes mellitus in rats. Acta Cirurgica Brasileira, 18, 60-64. http://dx.doi.org/10.1590/S0102-86502003001100009

[5]. Dhanani, T. Shah, S., Gajbhiye, N. A. \& Kumar, S. (2013). Effect of extraction methods on yield, phytochemical constituents and antioxidant activity of Withania somnifera, Arabian Journal of Chemistry, Available online 5 March 2013, ISSN ISSN 1878-5352.

http://dx.doi.org/10.1016/j.arabjc.2013.02.015

[6]. Doughari J. H. (2012). Phytochemicals: Extraction Methods, Basic Structures and Mode of Action as Potential Chemotherapeutic Agents, Phytochemicals - A Global Perspective of Their Role in Nutrition and Health, Dr Venkateswara Rao (Ed.), InTech. http://dx.doi.org/10.5772/26052

[7]. Emam, M. A. (2012). Comparative evaluation of antidiabetic activity of Rosmarinus officinalis L. and Chamomile recutita in streptozotocin induced diabetic rats. Agriculture and Biology Journal of North America, 3(6), 247-252. http://dx.doi.org/10.5251/abjna.2012.3.6.247.252

[8]. Farswan, M., Mazumder, P. M., Parcha, V. \& Upaganlawar, A. (2009). Modulatory effect of Syzygium cumini seeds and its isolated compound on biochemical parameters in diabetic rats. Pharmacognosy Magazine, 4(18), 127-133.

http://www.phcog.com/text.asp?2009/5/18/127/57970 
[9]. Grover N., Bafna, P. A. \& Rana, A. C. (2011). Diabetes and methods to induce experimental diabetes. International Journal of Pharmacy and Biological Sciences, 1, 414-419.

http://www.ijpbs.com/ijpbsadmin/upload/ijpbs_50c852159607d.pdf

[10]. Heroor, S., Arun, K. B. \& Nitin, M. (2013). Synergistic activity of bark extracts of pongamia glabra and ficus glomerata in alloxan-induced diabetic rats. World Journal of Pharmacy and Pharmaceutical Sciences, 2(6), 6640-6652.

[11]. Jonnalagadda, A., Karthik, K. M. \& Prem, K. N. (2013). Combined effect of Syzygium cumini seed kernel extract with oral hypoglycemics in diabetes induced increase in susceptability to ulcerogenic stimuli. Journal of Diabetes \& Metabolism, 4(1), 236-241. http://dx.doi.org/10.4172/2155-6156.1000236

[12]. Kulasekharam, K. (2014). Hepato-protective Activity of Aqueous Extract of Syzygium cumini seed on Streptozotocin Induced Diabetes in Rats. International Journal of Ayurvedic and Herbal Medicine, 4(2), 1470-1477.

[13]. Mastan, S. K., Latha, T. B., Latha, T. S., Srikanth, A., Chaitanya, G. \& Kumar, K. E. (2009). Influence of methanolic extract of Syzygium cumini seeds on the activity of gliclazide in normal and alloxan induced diabetic rats. Pharmacologyonline, 3, 845-850. http://pharmacologyonline.silae.it/files/archives/2009/vol3/092.Mastan.pdf

[14]. Maurya, A. K., Smriti, T., Monica, K., Zabeer, A. \& Sahu, R. K. (2011). Evaluation of antidiabetic effects of Ficus racemosa extracts in diabetic induced rats. Pharmacologyonline, 3, 907-914.

[15]. Nahar, L., Ripa, F. A., Zulfiker, A. H. M., Rokonuzzaman, M., Haque, M. \& Islam, K. M. S. (2010). Comparative study of antidiabetic effect of Abroma augusta and Syzygium cumini on alloxan induced diabetic rat. Agriculture and Biology Journal of North America, 1, 1268-1272. http://dx.doi.org/10.5251/abjna.2010.1.6.1268.1272

[16]. Nair, R. B. \& Santhakumari, G. (1986). Anti-diabetic activity of the seed kernel of Syzygium cumini Linn. Ancient Science of Life, 4(2), 80-84.

[17]. Patil, V. V., Sutar, N. G., Pimprikar, R. B., Patil, A. P., Chaudhari, R. Y. \& Patil, V. R. (2010). Antihyperglycemic and hypoglycemic effect of Ficus racemosa leaves. Journal of Natural Remedies, 10(1), 11-16.

[18]. Prasad, D. M., Rajyalakshmi, M. \& Jagadish, N. M. (2014). Ameliorative potential of aqueous leaves extract of Syzygium cumini (L) associated metabolic alterations in alloxan induced diabetic rats. Journal of Pharmacognosy and Phytochemistry, 3(3), 168-172.

[19]. Ramana, R. G., Siva, R. C. \& Chandana, V. R. (2011). Comparative and combined studies on antidiabetic, anti-oxidant and hypolipidemic effects of two plant extracts in STZ induced diabetic rats. Asian Journal of Traditional Medicines, 6(6), 231-241.

[20]. Rekha, N., Ramachandran, B. \& Munuswamy, D. (2008). Effect of aqueous extract of Syzygium cumini pulp on antioxidant defense system in streptozotocin induced diabetic rats. Iranian Journal of Pharmacology \& Therapeutics, 7(2), 137-145.

http://dx.doi.org/1735-2657/08/72-137-145.

[21]. Sachan, N. K., Kumar, Y., Pushkar, S., Thakur, R. N., Gangwar, S. S. \& Kalaichelvan, V. K. (2009). Antidiabetic potential of alcoholic and aqueous extracts of Ficus racemosa Linn. Bark in normal and alloxan induced diabetic rats. International Journal of Pharmaceutical Sciences and Drug Research, 1, 24-27.

[22]. Salim, A. A., Chin, Y. W. \& Kinghorn, A. D. (2008). Drug Discovery from Plants. In: K. G. Ramawat \& J. M. Mérillon (Eds.), Bioactive Molecules and Medicinal Plants, pp. 1-24. Cambridge, England: Cambridge University Press. http://dx.doi.org/10.1007/978-3-540-74603-4_1

[23]. Samyal, M. L., Zabeer, A., Shashi, B., Asha, B., Amit, D. \& Manju, S. (2014). Scientific validation of antidiabetic activity of ethanol extract of Ficus glomerata barks and roots in streptozotocininduced diabetic rats. UK Journal of Pharmaceutical and Biosciences, 2, 42-46. http://dx.doi.org/10.20510/ukjpb/2/i1/91155

[24]. Sarma, S. (2014). Role of Syzygium cumini seed-extract on streptozotocin-nicotinamideinduced type-2 diabetes of albino rat. International Journal of Pure \& Applied Bioscience, 2(4), 125-131.http://www.ijpab.com/form/2014\%20Volume\%202,\%20issue\%204/IJPAB-2014-24-125-131.pdf 
[25]. Satyanshu, K. (2015). Analytical Techniques for Natural Product Research. CABI, p. 256. https://cab.presswarehouse.com/Books/BookDetail.aspx?productID=468864

[26]. Saurabh, S., Preeti, B., Harish, D. \& Munish, G. (2015). Microwave Assisted Extraction of Tinospora cordifolia and Optimization through Central Composite Design. Journal of Biological Sciences, 15, 106-115. http:/dx.doi.org/10.3923/jbs.2015.106.115

[27]. Sikder, M. A. A., Kaisar, M. A., Rahman, M. S., Hussain, M. \& Rashid, M. A. (2011). Active Hypoglycemic Fraction from Syzygium cumini L. Seed and its Safety Profile. Bangladesh Pharmaceutical Journal, 14, 87-91.

[28]. Singh, N. \& Gupta, M. (2007). Effects of ethanolic extract of Syzygium cumini (Linn) seed powder on pancreatic islets of alloxan diabetic rats. Indian Journal of Experimental Biology, 45, 861-867.

http://nopr.niscair.res.in/bitstream/123456789/5343/1/IJEB\%2045\%2810\%29\%20861-867.pdf

[29]. Sophia, D. \& Manoharan, S. (2007). Hypolipidemic activities of Ficus racemosa Linn. bark in alloxan induced diabetic rats. African Journal of Traditional, Complementary and Alternative Medicines, 4, 279-288. http://dx.doi.org/10.4314/ajtcam.v4i3.31220

[30]. Sridhar, S. B., Sheetal, U. D., Pai, M. R. S. M. \& Shastri, M. S. (2005). Preclinical evaluation of the antidiabetic effect of Eugenia jambolana seed powder in streptozotocin-diabetic rats. Brazilian Journal of Medical and Biological research, 38, 463-468. http://dx.doi.org/10.1590/s0100-879x2005000300018

[31]. Sufiyan S., Bhaskar, S. \& Ram, G. (2014). Anti-hyperglycemic and Anti-hyperlipemia Effects of Syzygium Cumini Seed in Alloxan Induced Diabetes mellitus in Swiss Albino Mice (Mus musculus). Medicinal \& Aromatic Plants, 3(4), 166-171.

http://dx.doi.org/10.4172/2167-0412.1000166

[32]. Tiwari, P., Bimlesh, K., Mandeep, K., Gurpreet, K. \& Harleen, K. (2011). Phytochemical screening and Extraction: A Review. Internationale Pharmaceutica Sciencia, 1(1), 98-106. http://www.ipharmsciencia.com.

[33]. Varma, C., Fernandes, J., Ronald, F. \& Subramanyam, E. (2009). Hypoglycemic and antihyperglycemic activity of methanolic root extract of Ficus racemosa in normal and streptozotocin induced diabetic rats. Pharmacologyonline, 2, 656-666.

[34]. Vivek, K. S., Suresh, K., Hitesh, J. P. \& Shivakumar, H. (2010). Hypoglycemic activity of Ficus glomerata in alloxan induced diabetic rats. International Journal of Pharmaceutical Sciences Review and Research, 1, 18-22.

[35]. Zulfiker, A. H. M., Saha, M. R., Sarwar, S., Nahar, L., Hamid, K. \& Rana, M. S. (2011). Hypoglycemic and in vitro antioxidant activity of ethanolic extracts of Ficus racemosa Linn. fruits. American Journal of Scientific and Industrial Research, 2, 391-400. http://dx.doi.org/10.5251/ajsir.2011.2.3.391.400

\section{How to cite this article?}

\section{APA (American Psychological Association)}

Amin, M. M. \& Das, S. K. (2016). Copacetic herbal extraction techniques and diabetes induction methods for developing countries. Journal of Bioscience and Agriculture Research, 08(01), 703-709.

\section{MLA (Modern Language Association)}

Amin, M. M. \& Das, S. K. "Copacetic herbal extraction techniques and diabetes induction methods for developing countries". Journal of Bioscience and Agriculture Research, 08.01(2016), 703-709.

\section{Chicago/Turabian}

Amin, M. M. \& Das, S. K. "Copacetic herbal extraction techniques and diabetes induction methods for developing countries". Journal of Bioscience and Agriculture Research, 08, No. 01(2016), 703-709. 